\title{
PEMBERIAN HAK HADANAH KEPADA IBU TIRI DALAM PUTUSAN PENGADILAN AGAMA SIDOARJO NOMOR: 0763/PDT.G/2018/PA.SDA PERSPEKTIF MASLAHAH MURSALAH
}

\begin{abstract}
Wafda Firyal
MAS Al-Ma'arif Montong Are Kediri Lombok Barat. Email: firyal.uinsa@yahoo.com

Abstract: This article is a library research on the granting of rights to stepmothers in the decision of the Sidoarjo Religious Court Number: 0763/Pdt.G/2018/PA.Sda. The research data are collected using documentation techniques and are analysed using descriptive analysis techniques and using a deductive mindset that is by outlining the decision of the Sidoarjo Religious Court which is then reviewed from the perspective of maslahah mursalah. The panel of judges in determining the right of gift to stepmothers in the Sidoarjo Religious Court's decision, based on article 41 letter (a) of Law Number 1 of 1974 jo. article 105 and article 156 letter (a) Compilation of Islamic Law and the proposition in the book Bajurijuz. II. In addition, a willingness from the Defendant who is the biological father of the child to give the right of gift to the Plaintiff's Reconstruction is a point that is included as consideration by the panel of judges. In Islamic law which is examined from the theory of maslahah mursalah, the judge's consideration to establish the right of hadanah to the stepmother in the Sidoarjo Religious Court's ruling is in accordance with the purpose of the hadanah namely to prioritize the interests and benefit of the child so that later he or she can grow into a good person under the care of an appropriate person, even though the child is not a biological child of the Reconvention Plaintiff, the Reconvention Plaintiff is in fact more feasible and competent to have the right of hadanah.
\end{abstract}

Keywords: right of hadanah, stepmother, and maslahah mursalah

Abstrak: Artikel ini merupakan hasil penelitian pustaka (library research) tentang pemberian hak hadanah kepada ibu tiri dalam putusan Pengadilan Agama SidoarjoNomor: 0763/Pdt.G/2018/PA.Sda". Data penelitian dihimpun dengan menggunakan teknik dokumentasi dan dianalisis dengan menggunakan teknik deskriptif analisis yang menggunakan pola pikir deduktif yaitu dengan cara menguraikan putusan Pengadilan Agama Sidoarjo yang kemudian dikaji dari perspektif maslabah mursalah. Majelis hakim dalam menetapkan hak hadanah kepada ibu tiri pada putusan Pengadilan Agama Sidoarjo, didasarkan pada pasal 41 huruf (a) UndangUndang Nomor 1 Tahun 1974 jo. pasal 105 dan pasal 156 huruf (a) Kompilasi Hukum Islam serta dalil dalam kitab Bajuri juz II. Selain itu, adanya kerelaan dari Tergugat Rekonvensi yang merupakan ayah kandung dari anak tersebut untuk memberikan hak hadanah kepada Penggugat

AL-HUKAMA

The Indonesian Journal of Islamic Family Law Volume 09, Nomor 01, Juni 2019; ISSN:2089-7480 
Rekonvensi merupakan point yang dimasukkan sebagai pertimbangan oleh majelis hakim. Dalam hukum Islam yang dikaji dari teori maslahah mursalah, pertimbangan hakim untuk menetapkan hak hadanah kepada ibu tiri pada putusan pengadilan Agama Sidoarjo, telah sesuai dengan tujuan dari hadanah yaitu mengutamakan kepentingan dan kemaslahatan anak agar nantinya dapat tumbuh berkembang menjadi pribadi yang baik dibawah pengasuhan orang yang tepat, walaupun anak tersebut bukan merupakan anak kandung dari Penggugat Rekonvensi namun Penggugat Rekonvensi nyatanya lebih layak dan berkompeten untuk memiliki hak hadanah.

Kata Kunci: hak hadanah, ibu tiri, dan maslahah mursalah

\section{Pendahuluan}

Perkawinan memiliki tujuan diantaranya untuk mendapat keturunan. Setiap orang yang melaksanakna perkawinan tentu mempunyia keinginan memperoleh keturunan.1 Kehadiran anak dalam suatu perkawinan menurut Erna Wahyuningsih dan Putu Samawati, merupakan hak yang diimpikan setiap pasangan, merupakan karunia tuhan yang luar biasa, yang wajib dijaga dan dirawat dengan sebaik baiknya.2

Secara hukum, setiap anak mempunyai hubungan perdata dengan ayah kandung beserta keluarga ayah kandungnya dan juga mempunyai hubungan perdata dengan ibu kandung beserta keluarga ibu kandungnya. Hubungan perdata itu meliputi hubungan nasab (darah), hubungan perwalian dan hubungan kewarisan. Ketiga hubungan itu diperoleh secara "ijbari", artinya hubungan keperdataan dalam tiga bidang tersebut berlaku dengan sendirinya menurut ketetapan Allah tanpa digantungkan kepada kehendak orang tua atau anaknya.3

Namun terkadang perkawinan tidak selalu sesuai dengan yang diharapkan, berbagai permasalahan muncul sehingga berujung pada perceraian. Apabila perceraian terjadi, salah satu dampaknya ialah hak asuh anak yang dalam Islam disebut dengan istilah al-badanah. Menurut syari'at, hadanah artinya mengasuh dan menjaga bagi siapa

1 Soemyati, Hukum Perkawinan Islam dan Undang-Undang Perkawinan. (Yogyakarta: Liberty, 2007), 13.

2 Wahyu Ernaningsih dan Putu Samawati, Hukum Perkawinan Indonesia (Palembang: PT. Rambang Palembang, 2008), 129.

3 Abdul Wahid dan Muhibbin, Hukum Kewarisan Islam (Jakarta: Sinar Grafika, 2009), 23. 
yang tidak bisa mengurus dirinya sendiri dari hal-hal yang membahayakannya yang dilimpahkan bagi orang yang berhak mengasuhnya.4

Imam Sayyid Sabiq mendefenisikan hadanah sebagai lambung, seperti kata "badanah al-tha'iru baydabu" yang artinya burung itu mengapit telur di bawah sayapnya. Sedangkan dalam kalimat "badanah al-mar'atu waladaha", artinya seorang perempuan menggendong anaknya.5 Menurut Amir Syarifuddin dalam bukunya Hukum Perkawinan di Indonesia menyebutkan, bahwa badanah ialah pengasuhan anak yang masih kecil setelah terjadinya perceraian atau putusnya suatu perkawinan.6 Hadanah hukumnya wajib karena anak yang dipelihara akan terancam keselamatanya jika tidak diasuh, mengenai wajibnya hadanah bersamaan pula dengan kewajiban untuk menafkahinya.7

Menurut Soemiyati, jika terjadi perceraian di mana telah diperoleh keturunan dalam perkawinan itu maka yang berhak mengasuh anak hasil perkawinan adalah ibu atau nenek seterusnya ke atas.8 Adapun pendapat ulama yang ahli di bidangnya, hadanab itu berkaitan dengan tiga hak secara bersamaan, yaitu hak orang yang mengasuh, hak orang yang dipelihara dan hak ayah atau orang yang bertindak selaku yang mewakilinya. 9

Tidak jarang timbul permasalahan bilamana terjadi perceraian, mengenai siapakah di antara kedua orang tua yang lebih berhak terhadap anak dan selanjutnya melakukan tugas hadanah. Masalahnya

4 Wahbah Az Zuhaili, Fikih Islam Wa Adillatubu jilid 10, terj. Abdul Hayyi AlKatani (Jakarta: Gema Insani, 2011), 59.

5 Sayyid Sabiq, Fikib Sunnah, terj. Ali Nursyidi Hunainah dan M. Thahir Makmun (Jakarta: Pena Pundi Aksara, 2011), 21.

6Amir Syarifuddin, Hukum Perkawinan Islam di Indonesia: Antara Fikib Munakahat dan Undang-Undang Perkawinan (Kencana: Prenada Media, 2006), 327.

7 Wahbah Az Zuhaili, Fikib Islam Wa Adillatubu..., 60.

8 Soemyati, Hukum Perkawinan Islam..., 126.

9 Wahbah Az Zuhaili, Fikib Islam Wa Adillatubu..., 60-61. 
akan menjadi rumit bilamana masing-masing dari kedua orangtua tidak mau mengalah.10

Penyelesaian terhadap hak hadanah terdapat dalam hadits dibawah ini:

"Telah menceritakan kepada kami Mahmuud bin Khaalid AsSulamiy, Telah menceritakan kepada kami Al-Waliid, dari Abu 'Amru - yaitu Al-Auza'iy, Telah menceritakan kepadaku 'Amru bin Syu'aib, dari ayahnya, dari kakeknya 'Abdullah bin 'Amru: Bahwasannya ada seorang perempuan berkata: "Wahai Rasulullah, sesungguhnya anakku ini, perutku adalah tempatnya, dan puting susuku adalah tempat minumnya, dan pangkuanku adalah rumahnya; sedangkan ayahnya telah menceraikanku dan ingin memisahkanya dariku". Lalu Kemudian Rasulullah shallallaahu 'alaihi wa sallam berkata kepadanya: "Engkau lebih berhak terhadapnya selama engkau belum menikah".11

Wahbah Az Zuhaili, dalam bukunya Figh al-Islam Wa Adillatubu menyebutkan, pengasuh anak, yaitu seorang perempuan atau ibu haruslah:12

1. Perempuan itu tidak menikah kembali dengan laki-laki lain

2. Perempuan itu harus memiliki hubungan mahram dengan anak yang dipeliharanya.

3. Perempuan itu tidak pernah berhenti meskipun tidak diberi upah.

4. Perempuan tidak dapat mengasuh anak-anak dengan sikap yang tidak baik, seperti pemarah, orang yang dibenci oleh anak tersebut atau membenci anak-anak.

Abdul Azis Dahlan dalam buku Ensiklopedi Hukum Islam menyebutkan bahwa syarat khusus untuk pengasuh perempuan, menurut ahli fikih adalah:13

10Satria Effendi dan M. Zein, Problematika Hukum Keluarga Islam Kontemporer Analisis Yurisprudensi dengan Pendekatan Ushuliyah (Jakarta: Kencana, 2010), 167168.

11 Imam Abu Dawud, Sunah Abu Dawnd Juz. II, terj. Muhammad Nashiruddin AlAlbani (Jakarta: Pustaka Azzam, 2010), 383.

12 Wahbah Az Zuhaili, Fikib Islam Wa Adillatubu..., 68-69.

13 Abdul Azis Dahlan, Ensiklopedi Hukum Islam, cet. 3 (Jakarta: Ichtiar Baru Van Heove, 1999), 418. 
1. Perempuan itu belum kawin setelah dicerai oleh suaminya.

2. Perempuan itu harus mahram atau muhrim dari anak tersebut.

3. Pengasuh itu tidak mengasuh anak tersebut dengan marah dan kebencian

4. Apabila anak itu masih dalam usia menyusu pada pengasuhnya, tapi air susunya tidak ada atau ia enggan menyusukan anak itu, maka ia tidak berhak menjadi pengasuh anak itu.

Dalam perundang-undangan yang berlaku di Indonesia telah ditentukan urutan-urutan hak atas hadanah yang tercantum pula dalam Kompilasi Hukum Islam (KHI) Pasal 156 huruf (a) yaitu, anak yang belum mumayyiz berhak mendapatkan hadanah dari ibunya, kecuali bila ibunya telah meninggal dunia, maka kedudukannya digantikan oleh:14

1. Perempuan-perempuan dalam garis lurus ke atas dari ibu

2. Ayah

3. Perempuan-perempuan dalam garis lurus ke atas dari ayah

4. Saudara perempuan dari anak yang bersangkutan

5. Perempuan-perempuan kerabat sedarah menurut garis samping dari ibu

6. Perempuan-perempuan kerabat sedarah menurut garis samping ayah.

Disimpulkan bahwa dari segi hukum Islam maupun perundang-undangan yang berlaku di Indonesia, pemberian hak hadanah diutamakan kepada ibu kandung, setelah itu kerabat ibu barulah kepada ayah. Apabila dari beberapa golongan orang-orang yang memilihi hak atas hadanah tersebut dianggap tidak mampu sebagai seorang pengasuh, barulah diberikan kepada kerabat dekat. Kerabat adalah orang yang memiliki hubungan mahram dengan si anak.

Akan tetapi dalam putusan Pengadilan Agama Sidoarjo Nomor: 0763/ Pdt.G/ 2018/ PA.Sda hakim memutus untuk memberikan hak hadanah kepada ibu tiri yang telah bercerai dari ayah kandung si anak. Putusan hakim dalam hal ini adalah putusan yang

14 Undang-Undang Republik Indonesia Nomor 1 Tahun 1974 tentang Perkawinan \& Kompilasi Hukum Islam, cet. 6 (Bandung: Citra Umbara, 2015), 370. 
tidak sesuai dengan Kompilasi Hukum Islam pasal 105 huruf (a), bahwa anak yang masih belum mumayyiz masih berada di bawah pengasuhan ibu kandungnya serta tidak pula ditemukan ayat dalam Alqur'an maupun Hadist, mengenai pemberian hak hadanah kepada ibu tiri.

Dalam kaitannnya dengan masalah tersebut, penelitian ini ingin mengkaji dan membandingkan putusan hakim Pengadilan Agama Sidoarjo dengan kerangka hukum fikih melalui pendekatan maslahah mursalah. Untuk mengetahui apa saja dasar pertimbangan hakim dalam memutuskan perkara tersebut serta bagaimana tinjauan maslahah mursalah terhadap putusan hakim Pengadilan Agama Sidoarjo, maka penulis tertarik untuk melakukan penelitian dan membahasnya melalui penelitian dengan judul "Analisis Maslahah Mursalah Terhadap Pemberian Hak Hadanah Kepada Ibu Tiri Dalam Putusan Pengadilan Agama Sidoarjo Nomor: 0763/Pdt.G/2018/PA.Sda".

\section{Hadanah}

1. Pengertian Hadanah

Dalam Islam pengasuhan anak lebih dikenal dengan nama hadanah. Secara etimologis hadanah berasal dari kata hadanah yang artinya memeluk, mendekap, mendidik, mengasuh, dan mengerami. Dalam pengertian lain hadanah berasal dari kata bidanah yang berarti pangkuan dan dada. Selain itu, kata hadanatu berarti perawatan dan pengasuhan, sementara kata bidanatu berarti pendidikan, penguasaan, nasihat.15 Menurut terminologis yang dimaksud dengan hadhanah atau pengasuhan anak adalah kegiatan mengasuh, mengasuh dan mendidik anak hingga dewasa atau mampu berdiri sendiri.16

Secara terminologi, para tokoh Islam memberikan berbagai definisi berkenaan dengan arti hadanah. Salah satu pengertian hadanah tersebut diberikan oleh Sayyid Sabiq yang mengartikan badanah adalah melakukan pengasuhan anak-anak yang masih kecil laki-laki atau perempuan atau sudah besar, tetapi

15 Ali Atabiq dan Ahmad Zuhdi Muhdlar, Kamus Kontemporer Arab-Indonesia (Yogyakarta: Yayasan Ali Maksum Pondok Pesantren Krapyak, 1996), 775-776. 16 Nur Djamaan, Fikih Munakahat (Semarang: Dina Utama, 1993), 119. 
belum mumayyiz atau yang kurang akalnya, belum dapat membedakan antara yang baik dan buruk, belum mampu dengan bebas mengurus diri sendiri dan belum tahu mengerjakan sesuatu untuk dan mengasuh dari suatu yang menyakiti dan membahayakannya, mendidik serta mengasuhnya, baik fisik maupun mental atau akalnya agar mampu menempuh tantangan hidup serta memikul tanggung jawab.17 Hadanah juga diartikan sebagai: "asuhan terhadap seorang anak kecil untuk dididik dan diurus semua urusannya"18.

Adapun dalam kitab Kifayatul Akhyar disebutkan bahwa badanab adalah:

"Suatu sikap untuk menjaga seseorang yang belum tamyiz dan belum bisa menjaga dirinya sendiri, kemudian mendidiknya dengan sekiranya dia itu menjadi anak yang baik dan melindunginya dari suatu ancaman yang dapat membahayakannya".

Para tokoh mengemukakan beberapa definisi tentang badanah, yaitu:

a. Abdul Azis Dahlan menyebutkan bahwa badanah adalah merawat dan mendidik seseorang yang belum mumayyiz atau yang kehilangan kecerdasannya karena mereka tidak bisa mengerjakan keperluan diri sendiri.19 Ulama fikih menetapkan bahwa kewenangan seperti itu lebih tepat dimiliki oleh kaum wanita, karena naluri kewanitaan mereka lebih sesuai untuk merawat dan mendidik anak, serta kesabaran mereka dalam menghadapi permasalahan kehidupan anak-anak lebih tinggi dibandingkan kesabaran seorang laki-laki.20

b. Menurut Amir Syarifuddin dalam bukunya Hukum Perkawinan di Indonesia, ia menyebutkan, bahwa kata hadanah adalah pengasuhan anak yang masih kecil setelah terjadinya perceraian atau putusnya suatu perkawinan. Dalam kajian fikih terdapat dua kata mengenai pengasuhan anak, namun

17 Sayyid Sabiq, Fikih Al-Sunnah III, terj. Nor Hasanuddin ..., 288.

18 Muhammad Rawwas Qal'ahji, Ensiklopedi Fikih Umar Bin Khathab, terj. M.Abdul Mujeb (Jakarta: Raja Grafindo Persada, 1999), 103.

19 Abdul Azis Dahlan, Ensiklopedi Hukum ..., 415.

20 Ibid. 
mempunyai arti yang sama, yaitu kafalah dan hadanah. Kafalah dan hadanah adalah pengasuhan anak yang masih kecil setelah putusnya hubungan perkawinan.21

c. Andi Syamsu Alam menyebutkan timbulnya hadanab yaitu ada kalanya disebabkan terjadinya perceraian sebagaimana pendapat Amir Syarifuddin, dan ada kalanya disebabkan meninggal dunia, sehingga anak yang belum dewasa tidak mampu mengurus dirinya.22

d. As-San'ani memaknai hadanah sebagai pengasuhan atas anak yang belum mampu berdiri sendiri mengenai dirinya, pendidikannya serta pengasuhannya dari segala sesuatu yang membinasakannya atau yang membahayakannya.23

Undang-Undang Nomor 1 Tahun 1974 tidak meyebutkan pengertian pengasuhan anak (badanab) secara definitif, melainkan hanya disebutkan tentang kewajiban orang tua untuk mengasuh anaknya. Pasal 45 ayat (1) Undang-Undang ini disebutkan bahwa, "Kedua orang tua wajib mengasuh dan mendidik anak-anak mereka sebaik-baiknya". Terdapat sebuah ungkapan yaitu, badanah al-tha'iru baydabu, berarti seekor burung yang menghimpit telurnya (mengerami) di antara kedua sayap dan badannya, demikian juga jika seorang ibu membuai anaknya dalam pelukan atau lebih tepat jika dikatakan mengasuh dan mendidik anaknya.24

Hadanah berbeda maksudnya dengan pendidikan. Dalam hadanah terkandung pengertian pengasuhan jasmani dan rohani, di samping terkandung pula pengertian pendidikan terhadap anak. Pendidik mungkin terdiri dari keluarga si anak dan mungkin bukan dari keluarga si anak dan ia merupakan pekerjaan profesional, sedangkan badanab dilaksanakan dan dilakukan oleh keluarga si anak, kecuali jika anak tidak mempunyai keluarga serta

21 Amir Syarifuddin, Hukum Perkawinan Islam di Indonesia..., 327.

22 Andi Syamsu Alam dan M. Fauzan, Hukum Pengangkatan Anak Perspektif Islam (Jakarta: Kencana Prenada Media Group, 2008), 114-115.

23 As-San'ani, Subulus Salam, terj. Abu Bakar Muhammad cet. 3 (Surabaya: Al Ikhlas, 1995), 37.

24 M. Abdul Ghofar, Fikih Wanita (Edisi Lengkap), terj. dari Al-Jami' Fii Fikihi AnNisa' cet. 20 (Jakarta: Pustaka Al-Kautsar, 2006), 454. 
ia bukan profesionall dilakukan oleh setiap ibu, serta anggota kerabat yang lain. 25

Dari beberapa pendapat di atas dapat disimpulkan, bahwa pengasuhan anak atau hadanah mengandung arti tanggung jawab orang tua atau kerabat sedarah jika kedua orangtuanya telah tiada, untuk mengawasi, memberi pelayanan yang semestinya, serta mencukupi kebutuhan hidup seorang anak. Tanggung jawab pengasuhan tersebut berupa pengawasan dan pelayanan serta pencukupan nafkah anak tersebut mencapai batas umur yang legal sebagai orang dewasa yang telah mampu berdiri sendiri.26

2. Dasar Hukum Hadanah

Kewajiban hadanab bukan hanya berlaku selama ayah dan ibu masih terikat dalam tali perkawinan saja, namun juga berlanjut setelah terjadinya perceraian. Pengasuhan anak dilakukan oleh orang tua atau kerabat sampai anak tersebut telah mampu berdiri sendiri, anak-anak harus dijaga, dirawat dan di didik dengan baik. Firman Allah dalam Q.S at-Tahrim ayat 6:

Hai orang-orang beriman, peliharalab dirimu dan keluargamu dari siksaan api neraka yang bahan bakarnya adalah manusia dan batubatu, sedang penjaganya malaikat-malaikat yang kasar lagi keras, mereka tiada mendurbakai Allab tentang apa-apa yang disurub-Nya dan mereka memperbuat apa-apa diperintabkan kepadanya.27

Ayat di atas merupakan perintah untuk menjaga diri dan keluarga dari siksa api neraka yaitu dengan melaksanakan perintah-perintah Allah dan meninggalkan larangan-Nya.28 Oleh karena itu, menjaga dan mendidik anak-anak yang masih belum mumayyiz, hukumnya wajib, sebab mengabaikannya berarti menghadapkan anak-anak tersebut kepada bahaya kebinasaan.

25 Zakiyah Daradjat, Ilmu Fikih, jilid 2 (Yogyakarta: Dana Bhakti Wakaf, 1995), 157- 158.

26 Amiur Nuruddin Dan Azhari Akmal Tarigan, Hukum Perdata Islam di Indonesia, Studi Kritis Pekembangan Hukum Islam Dan Fikih, UU No. 1/1974 Sampai KHI (Jakarta: Kencana Prenada Media Group, 2006), 293-294.

27 Departemen Agama RI, Al-Quran Dan Terjemahnya..., 560.

28 Abdul Rahman Ghazaly, Fikih Munakahat, cet. 3 Jakarta: Pranada Media Gruop, 2003), 177. 
Hadanah sendiri merupakan hak bagi anak-anak yang masih kecil atau belum mumayyiz, karena ia masih membutuhkan pengawasan dan penjagaan dari orang yang mendidiknya terutama ibunya yang berkewajiban melakukan hadanah.29

Mengenai pengasuhan anak atau badanah disebutkan pula dalam Firman Allah QS. Al-Baqarah 233:

"Para ibu hendaklah menyusukan anak-anaknya selama dua tabun penub, yaitu bagi yang ingin menyusui secara sempurna. Dan kewajiban ayah memberi makan dan pakaian kepada para ibu dengan cara ma'ruf. Seorang tidak dibebani lebib dari kesanggupannya. Janganlah seorang ibu menderita karena anaknya dan jangan pula seorang ayah menderita karena anaknya. Abli waris pun berkewwajiban seperti itu pula. Apabila keduanya ingin menyapib (sebelum dua tahun) dengan persetujuan dan permusyawaratan antara keduanya, maka tidak ada dosa atas keduanya. Dan jika kamu ingin menyusukan anakmu kepada orang lain, maka tidak ada dosa bagimu memberikan pembayaran menurut yang patut. Bertakwalah kamu kepada Allah dan ketabuilah bahwa Allah maba melihat apa yang kamu kerjakan".30

Ayat di atas secara eksplisit tidak menegaskan bahwa tanggung jawab pengasuhan anak menjadi beban yang harus di penuhi suami sebagai ayah, namun pembebanan ayah untuk memberi makan dan pakaian. Kepada ibu, melekat di dalamnya tanggung jawab pengasuhan anak. Hal ini diperkuat lagi dengan ilustrasi apabila anak tersebut disusukan oleh wanita lain yang bukan ibunya sendiri, maka ayah bertanggung jawab untuk membayar perempuan yang menyusuinya. 31

Adapun ketentuan di atas lebih mengatur kewajiban orang tua, sedangkan mengenai sifat yang harus dimiliki oleh orang tua sebagai pemegang hak hadanah ialah: memiliki sifat yang arif, penuh perhatian dan kesabaran sehingga seseorang

29 Tihami dan Sahari Sahrani, Fikih Munakahat: Kajian Fikih Nikah Lengkap, cet. 7 (Jakarta: Rajawali Pers, 2010), 217.

30 Departemen Agama RI, Al-Qur'an Dan Terjemah....,24.

31 Ahmad Rofiq, Hukum Islam DI Indonesia, cet. 3 (Jakarta, Raja Grafindo Persada, 1998), 237. 
makruh mencela anaknya ketika dalam hadanah, sebagaimana makrubya mengutuk diri sendiri, pembantu, dan hartanya. Karena Rasulullah saw bersabda:32

"Telah menceritakan kepada Jabir Ibn Abdullah berkata: Rasulullah saw bersabda: Janganlah kamu menyumpahi (mendoakan jelek) diri sendiri, janganlah kalian menyumpahi anak kalian, janganlah kalian menyumpahi pembantu kalian, dan janganlah kalian menyumpahi harta kalian. Janganlah kalian menyumpahi sesuatu terlebih ketika Allah mengabulkan permintaan."

Di dalam fikih Syafi'i disebutkan pula hadis:

"Bila seorang laki-laki menceraikan istrinya, sedangkan ia mempunyai anak dari istri tersebut, maka istri itulah yang lebih berhak mengasuh anak tadi sampai ia berusia 7 tahun. Kemudian (sesudah itu) anak tadi disuruh memilih antara kedua orang tuanya. Kepada siapa ia memilih, maka diserahkan kepadanya". Adapun syaratsyarat hadanah itu ada tujuh, yaitu orang yang berakal, dewasa dan beragama Islam, tanggung jawab, tidak terganggu ingatan, dapat dipercaya (amanah), lalu memiliki kemampuan untuk melakukan hadhanah, dan bersatu dengan suami. Maka sesungguhnya persyaratan itu harus telah dipenuhi semuanya".33

Berdasarkan hadits di atas, terselip makna bahwa seorang ibu lebih berhak mendidik anaknya daripada seorang ayah, karena ia lebih berpengalaman dan lebih sabar dalam hal tersebut. Para ulama pun telah sepakat bahwa ibu lebih berhak atas anaknya yang belum mumayyiz daripada ayahnya. Akan tetapi, dalam suatu perkara diceritakan oleh Ibnu Mundzir bahwa hak seorang ibu di dalam mendidik anaknya akan

32 Abi Daud Muhammad Syamsi, Aunul Ma'bud, jilid 2 (Beirut: Dar Al-Kitab AlIlmiah), 274-275.

33 Mustofa Diibulbigha, Fikih Syafi'i, terj. Attahdzi Adlchiyah Sunarto dan M. Multazam (Bandung: CV Bintang Pelajar, 1998), 427. 
hilang apabila ia menikah lagi dengan laki-laki lain34, seperti yang tertera pada hadits di bawah ini:35

"Dari Abdullah Ibnu Amar bahwa ada seorang perempuan berkata: wahai Rasulullah, sesungguhnya anakku ini perutkulah yang mengandungnya, susuku yang memberinya minum, dan pangkuanku yang melindunginya. Namun ayahnya yang menceraikanku ingin merebutnya dariku. Maka Rasulullah Shallallaahu 'alaihi wa Sallam bersabda kepadanya: "Engkau lebih berhak terhadapnya selama engkau belum nikah."

Dari hadits di atas, dapat diketahui, bahwa apabila seorang suami menceraikan istri sedangkan ia memiliki seorang anak darinya, maka sang istri lebih berhak untuk memelihara anak tersebut sampai ia baligh dan selama ia tidak menikah dengan laki-laki lain. Akan tetapi, apabila anak sudah berusia tujuh tahu, maka ia dapat memilih antara ikut ayah atau ibunya. Hal ini sesuai dengan hadits Rasulullah dibawah ini: 36

"Dari Abu Hurairah Radliyallaahu 'anhu bahwa seorang perempuan berkata: Wahai Rasulullah, suamiku ingin pergi membawa anakku, padahal ia berguna untukku dan mengambilkan air dari sumur Abu 'Inabah untukku. Nabi Shallallaahu 'alaihi wa Sallam bersabda: "Wahai anak laki, ini ayahmu dan ini ibumu, peganglah tangan siapa dari yang engkau kehendaki." Lalu ia memegang tangan ibunya dan ia membawanya pergi”

Berdasarkan dua hadits di atas dapat disimpulkan, bahwa hak hadanah bagi anak yang orang tuanya bercerai memiliki dua macam ketentuan yaitu, jika ia masih kecil (belum mumayyiz), maka yang berhak untuk memeliharanya adalah ibunya. Namun, apabila ia sudah dapat membedakan mana yang baik dan mana yang buruk, maka anak tersebut

34 Wahbah Az Zuhaili, Fikih Isam Wa Adillatubu ..., 68.

35Ibnu Hajar Atsqalani, Bulughul Maram, terj. Prof. KH. Masdar Helmy (Bandung: Gema Risalah Pres Bandung, 1996), 253.

36 Ibnu Hajar Atsqalani, Bulughul Maram ..., 254. 
berhak untuk menentukan dengan siapa ia akan ikut. Selain itu, terdapat pula ketentuan bahwa hak hadanah bagi anak yang ibunya atau kedua orang tuanya meninggal, maka orang yang paling dekat yang berhak untuk mengasuhnya adalah bibinya yang berasal dari pihak ibunya. Hal ini berdasarkan pada hadits dibawah ini yang menyatakan bahwa kedudukan bibi (saudara perempuan ibu) itu adalah sama kedudukannya dengan ibu.37

'Barra' Ibnu 'Azb bahwa Nabi Shallallaahu 'alaihi wa Sallam telah memutuskan puteri Hamzah agar dipelihara saudara perempuan ibunya. Beliau bersabda: "Saudara perempuan ibu (bibi) kedudukannya sama dengan ibu."

Dasar hukum mengenai pengasuhan terhadap anak atau hadanah selain terdapat dalam Alqur'an dan Sunnah Rasul, juga dapat dilihat pada Undang-Undang No.1 Tahun 1974 Tentang Perkawinan yang berlaku di Indonesia. Mengenai kewajiban terhadap anak disebutkan dalam Pasal 45 yang isinya ialah bahwa kedua orang tua wajib mengasuh anak-anak mereka sebaik-baiknya, kewajiban orang tua yang disebut berlaku sampai anak kawin atau dapat berdiri sendiri dan kewajiban tersebut berlaku meskipun perkawinan kedua orang tuanya telah putus.

Dalam pasal 49 mengenai pengasuhan anak, bahwa salah seorang atau kedua orang tua dapat dicabut kekuasaannya terhadap seorang anak atau lebih untuk waktu tertentu atas permintaan orang tua yang lain, keluarga anak dalam garis lurus ke atas dan saudara kandung yang telah dewasa atau pejabat yang berwenang, dengan keputusan Pengadilan apabila ia sangat melalaikan kewajibannya terhadap anaknya ataupuan ia berkelakuan buruk sekali. Akan tetapi jika memang orang tua dicabut kekuasaannya, mereka

37 Ibid. 
masih berkewajiban untuk memberi biaya pengasuhan kepada anak tersebut.38

Kompilasi Hukum Islam, membahas mengenai pengasuhan anak pada pasal 98, pasal 105 dan pasal 156 yang dijelaskan sebagai berikut: Batas usia anak yang mampu berdiri sendiri adalah 21 tahun, selama dalam pengasuhan orang tua segala perbuatan hukum anak diwakilkan oleh orang tuanya, hak hadanah anak yang belum mencapai umur 12 tahun adalah hak ibunya, hak hadanah anak yang sudah mecapai umur 12 tahun diberikan kepada anak untuk memilih antara ayah atau ibunya.

Pemegang hak hadanah yang tidak mampu menjamin keselamatan jasmani dan rohani anak hak hadanahnya dapat dicabut dan dilimpahkan kepada kerabat yang lain, biaya pengasuhan dan pendidikan anak merupakan kewajiban ayahnya apabila dalam kenyataannya ayah tidak mampu memenuhi kewajiban tersebut Pengadilan Agama dapat menentukan ibu untuk ikut menanggung biaya tersebut.39

Berdasarkan ketentuan di atas, dari dalil Alqur'an, hadits, dan Undang-Undang No. 1 tahun 1974 tentang perkawinan dapat diketahui bahwa hadanah (pengasuhan anak) merupakan kewajiban, tuntutan secara sadar bagaimana pentingnya pengasuhan anak semenjak dari kecil, bahkan badanah merupakan syari'at agama yang harus dipenuhi orang tua.

3. Kewajiban dan Hak Pemegang Hadanah

Pada dasarnya tanggung jawab pengasuhan anak atau badanah menjadi beban orang tuanya, baik kedua orang tuanya masih hidup rukun atau ketika perkawinan mereka gagal karena perceraian. Dalam hal ini ibu mendapat prioritas utama untuk mengasuh selama anak tersebut belum mumayyiz: Jika terjadi perselisihan antara suami dan istri mengenai

38 Depertemen Agama RI, Himpunan Perundang-Undangan Perkawinan, cet. 3 (Jakarta: Aneka Ilmu, 2001), 22.

39 Undang-Undang Republik Indonesia Nomor 1 Tahun 1974 Tentang Perkawinan ..., 352-354. 
penguasaan anak-anak maka dapat diselesaikan melalui jalur musyawarah keluarga ataupun dengan putusan Pengadilan.40

Pelimpahan hak atas hadanah seringkali terjadi perselisihan, namun jika memang terjadi maka yang lebih didahulukan adalah pihak perempuan daripada pihak laki-laki apabila derajat kekeluargaan keduanya dengan anak adalah sama. Jika keluarga terdekat tidaklah mampu untuk menjadi seorang pengasuh maka didahulukan unruk kerabat yang lebih dekat.

Kompilasi Hukum Islam mengatur lebih rinci dan tertera pada pasal 105, dalam hal terjadinya perceraian maka pengasuhan anak yang belum mumayyiz atau belum berumur 12 tahun adalah hak ibunya, pengasuhan anak yang sudah mumayyiz diserahkan kepada anak untuk memilih diantara ayah atau ibunya sebagai pemegang hak pengasuhannya dan biaya pengasuhan ditanggung oleh ayahnya.41 Hal tersebut juga relevan dengan pasal 149 huruf (d) yang berisikan, bilamana perkawinan putus karena talak, maka bekas suami wajib memberikan biaya hadhanah untuk anak-anaknya yang belum mencapai umur 21 (dua puluh satu) tahun.

Hal tersebut menjadi semakin jelas seiring dengan yang tertera dalam pasal 159 mengenai akibat putusnya perkawinan karena perceraian yaitu anak yang belum mumayyiz berhak mendapatkan hadanah dari ibunya, kecuali bila ibunya telah meninggal dunia, maka kedudukannya digantikan oleh wanitawanita dalam garis lurus dari ibu, ayah, wanita-wanita dalam garis lurus ke atas dari ayah, saudara perempuan dari anak bersangkutan, wanita-wanita kerabat sedarah menurut garis samping dari ibu, wanita-wanita kerabat sedarah menurut garis samping dari ayah.42

Bagi anak yang sudah mumayyiz maka ia berhak memilih untuk mendapatkan hadanah dari ayah atau ibunya, jika kemudian hari pemegang hadanah ternyata tidak dapat

40 Amiur Nuruddin dan Azhari Akmal Tarigan, Hukum Perdata Islam ..., 295.

41 Undang-Undang Republik Indonesia Nomor 1 Tahun 1974 Tentang Perkawinan ..., 354 .

42 Ibid. 
menjamin keselamatan jasmani dan rohani anak, meskipun biaya nafkah dan hadanah telah tercukupi, maka atas permintaan kerabat yang bersangkutan, pengadilan agama dapat memindahkan hak hadanab kepada kerabat lain yang mempunyai hak hadanah pula. Persoalan mengenai biaya badanah dan nafkah anak menjadi tanggungan ayah menurut kemampuannya, sekurang-kurangnya sampai anak tersebut dewasa dan dapat mengurus diri sendiri (21) tahun.43

Perselisihan mengenai hadanab dan nafkah anak seringkali terjadi, namun apabila tidak dapat dihindari maka Pengadilan Agama dapat memberikan putusannya berdasarkan poin-poin yang telah disebutkan ditas, mengenai nafkah sendiri pengadilan dapat menilai dari kemampuan ayahnya dalam menetapkan jumlah biaya untuk pengasuhan dan pendiidkan anak-anak yang tidak turut kepadanya.44

Syaikh Hasan Ayyub didalam kitab Fikih Keluarga, membahas tentang susunan keluarga yang berhak dalam mengasuh anak setelah terjadi perceraian antara suami istri. Sebagaimana hak hadanah pertama diberikan kepada ibu, maka para ahli fikih menyimpulkan, bahwa keluarga ibu dari seorang anak lebih berhak daripada keluarga ayahnya.

Berikut adalah urutan pemegang hak hadanah : ibu anak tersebut, nenek dari ibu dan terus ke atas, nenek dari pihak ayah, saudara kandung anak, saudara perempuan seibu, saudara perempuan seayah, anak perempuan dari saudara perempuan sekandung, anak perempuan dari saudara perempuan seayah, saudara perempuan seibu dan sekandung dengannya, saudara perempuan ibu yang seibu dengannya (bibi), saudara perempuan ibu dan seayah dengannya (bibi), anak perempuan dari saudara perempuan seayah, anak perempuan dari saudara laki-laki kandung, anak perempuan dari saudara laki-laki seibu, anak perempuan dari saudara lakilaki seayah, bibi yang sekandung dengan ayah, bibi yang seibu

43 Ibid., 370.

44 Undang-Undang Republik Indonesia Nomor 1 Tahun 1974 Tentang Perkawinan ..., 370 . 
dengan ayah, bibi yang seayah dengan ayah, bibi ibu dari pihak ibu, bibinya ayah dari pihak ibunya, bibi ibu dari pihak ayahnya, dan yang terakhir ialah bibi ayah dari pihak ayah. 45

Dari semua perempuan yang berhak mengasuh anak seperti yang telah disebutkan di atas, saudara sekandung lebih didahulukan.46 Jika tidak ada yang akan melakukan hadanah pada tingkat perempuan, maka yang melakukan hadanab ialah pihak laki-laki yang urutannya sesuai dengan urutan perempuan di atas dan jika pihak laki-laki juga tidak ada, maka kewajiban melakukan badanah itu merupakan kewajiban perintah.

Dasar urutan orang-orang yang berhak melakukan badanah selanjutnya ialah:47

a. Kerabat pihak ibu didahulukan atas kerabat pihak ayah jika tingkatannya dalam kerabat adalah sama.

b. Nenek perempuan didahulukan atas saudara perempuan, karena anak merupakan bagian dari kakek, karena itu nenek lebih berhak dibanding dengan saudara perempuan.

c. Kerabat sekandung didahulukan dari kerabat yang bukan sekandung dan kerabat seibu lebih didahulukan atas kerabat seayah.

d. Dasar urutan ini ialah urutan kerabat yang ada hubungan mahram, dengan ketentuan bahwa pada tingkat yang sama pihak ibu didahulukan atas pihak ayah.

e. Apabila kerabat yang ada hubungan mahram tidak ada maka hak hadanah pindah kepada kerabat yang tidak ada hubungan mahram.

Selanjutnya meskipun anak itu dalam pengasuhan ibunya, maka ia tidak berhak melarang ayahnya untuk mengunjunginya dan membawanya ke kantor atau tempat lainnya, dan setelah itu ia dikembalikan lagi kepada ibunya. Begitu pula sebaliknya jika anak itu berada di bawah

45 Syaikh Hasan Ayyub, Fikih Keluarga Panduan Membangun Keluarga Sakinah Sesuai Syariat, terj. M. Abdul Ghoffar cet. 5 (Jakarta Timur: Pustaka Al-Kautsar, 2006), 394.

46 Sayyid Sabiq, Fikih Sunnah, terj. Nor Hasanuddin ..., 24-25.

47 Abdul Rahman Ghazaly, Fikih Munakahat..., 181. 
pengasuhan ayah, maka ia tidak berhak menghalangi anaknya itu untuk mengunjungi ibunya atau menghalangi ibunya mengunjungi anaknya tersebut.48

Mengenai kewajiban untuk menjalankan hadhanah memiliki batasan atau masa berlaku yang akan berakhir apabila anak tersebut sudah tidak lagi memerlukan pelayanan, telah dewasa dan dapat berdiri sendiri serta telah mampu untuk memenuhi kebutuhan pokoknya. Dalam hal ini tidak ada batasan waktu untuk masa berlkunya melainkan dilihat dari segi tamyiz dan kemampuan untuk mengurus diri sendiri.49

Dalam buku Al-Fiqh 'Ala Al-Madz̧hab Al-Khamsah karya Muhammad Jawad Mughniyah dituliskan pendapat-pendapat ulama lima mazhab mengenai batas hadhanah sebagai berikut:50

a. Hanafi berpendapat: masa asuhan adalah tujuh tahun bagi laki-laki dan sembilan tahun untuk perempuan.

b. Syafi'i mengatakan: tidak ada batasan tertentu bagi asuhan. Anak tetap tinggal bersama ibunya sampai dia bisa menentukan pilihan apakah bersama ibu atau ayahnya.

c. Maliki berpendapat: masa asuh anak laki-laki adalah sejak dilahirkan hingga baligh, sedangkan anak perempuan hingga menikah.

d. Hambali: masa asuh anak laki-laki dan perempuan adalah tujuh tahun, sesudah itu si anak disuruh memilih apakah tinggal bersama ibu atau ayahnya, lalu si anak tinggal bersama orang yang dipilihnya itu.

e. Imamiyah: masa asuh untuk anak laki-laki dua tahun, sedangkan anak perempuan tujuh tahun. Sesudah itu hak ayahnya, hingga dia mencapai usia sembilan tahun bila dia perempuan dan lima belas tahun bila laki-laki, untuk

48 Syaikh Hasan Ayyub, Fikih Keluarga Panduan Membangun Keluarga Sakinah Sesuai Syariat, terj. Abdul Ghofar ..., 457.

49 Slamet Abidin dan H. Aminuddin, Fikih Munakahatii, cet. 1 (Bandung: Cv Pustaka Setia, 1999), 183.

50 Muhammad Jawad Mughniyah, Al-Fikih 'Ala Al-Madzhab Al-Khamsah, terj. Masykur A.B dan Afif Muhammad cet. 1 (Jakarta: Lentera, 1996), 417-418. 
kemudian disuruh memilih dengan siapa dia ingin tinggal: ibu atau ayahnya.

\section{Syarat Hadanah}

Bagi orang yang hendak mengasuh baik laki-laki maupun perempuan ditetapkan syarat-syarat yang apabila salah satunya tidak dipenuhi maka gugurlah hak sebagai pemegang hadanah, diantaranya adalah sebagai berikut:51

a. Baligh: anak kecil atau yang belum baligh tidak boleh menjaid hadhin untuk orang lain, karena dia sendiir belum mampu untuk mengurus dirinya sendiri.

b. Berakal: orang gila dan idiot tidak boleh menjadi hadhin karena merek ajuga masih memerlukan bantuan orang untuk mengurus dirinya sendiri. Ulama malikiyyah mensyaratkan seorang hadhin haruslah cerdas dan tidak boros. Ulama Malikiyyah dan Hanabilah mensyaratkan seorang hadhin tidak mengidpa penyakit yang membuatnya dijauhi orang seperti kista atau lepra.

c. Memiliki kemampuan untuk mendidik yang diasuh dan juga mampu untuk menjaaga kesehatan dan kepribadian anak. Jadi orang lemah dan wanita karir yang sibuk dengan pekerjaannya sehingga tidak punya waktu untuk mendidik anak juga tidak termasuk kategori orang yang berhak menerima hadanah.

d. Mempunyai sifat amanah, yang tidak termasuk sifat amanah ialah: fasik, pemabuk, pezina, sering melakukan perkara haram.

e. Orang yang mengurus hadanah anak disyaratkan harus beragama Islam menurut Syafi'iyah dan Hanabilah.

\section{Maslahah Mursalah}

1. Pengertian Maslahab Mursalah

Menurut bahasa, kata maslahah berasal dari Bahasa Arab dan telah dibakukan ke dalam Bahasa Indonesia menjadi kata maslahah, yang berarti mendatangkan kebaikan atau yang

51 Wahbah Az-Zuhaili, Fikih Islam Wa Adilatubu..., 66-67. 
membawa kemanfaatan dan menolak kerusakan.52 Menurut bahasa aslinya kata maslahah berasal dari kata, salaha - yaslihu salahan artinya sesuatu yang baik, patut, dan bermanfaat.53 Sedang kata mursalah artinya terlepas bebas, tidak terikat dengan dalil agama (Al-Qur'an dan al-Hadits) yang membolehkan atau yang melarangnya. 54

Menurut Prof. Dr. Rachmat Syafe'i, arti maslabah mursalah secara lebih luas, yaitu suatu kemaslahatan yang tidak mempunyai dasar dalil, tetapi juga tidak ada pembatalnya. Jika terdapat suatu kejadian yang tidak ada ketentuan syari'at dan tidak ada 'illat yang keluar dari syara' yang menentukan kejelasan hukum kejadian tersebut, kemudian ditemukan sesuatu yang sesuai dengan hukum syara, yakni suatu ketentuan yang berdasarkan pengasuhan kemudharatan atau untuk menyatakan suatu manfaat maka kejadian tersebut dinamakan maslahah mursalah.55

Tujuan utama maslahah mursalah adalah kemaslahatan, yakni mengasuh dari kemudharatan dan menjaga kemanfaatannya.56 Sedangkan menurut Muhammad Abu Zahra, definisi maslahah mursalah adalah segala kemaslahatan yang sejalan dengan tujuantujuan syari' (dalam mensyari'atkan hukum Islam) dan kepadanya tidak ada dalil khusus yang menunjukkan tentang diakuinya atau tidaknya.57

Dari beberapa rumusan pengertian di atas, diketahui tentang hakikat dari maslahah mursalab tersebut, sebagai berikut:58 a. Ia adalah sesuatu yang baik menurut akal dengan pertimbangan dapat mewujudkan kebaikan atau menghindarkan keburukan bagi manusia;

52 Kholil Munawar, Kembali Kepada al-Quran dan as-Sunnah (Jakarta: Bulan Bintang, 1965), 43.

53 Muhammad Yunus, Kamus Arab Indonesia (Jakarta: Yayasan Penyelenggaraan Penerjemah dan Penafsir al-Qur'an, 1973), 219.

54 Kholil Munawar, Kembali Kepada al-Quran ..., 43.

55 Rachmat Syafe'i, Ilmu Ushul Fikih (Jakarta: Prenada Media Group, 2010), 117. 56 Ibid.

57 Muhammad Abu Zahrah, Ushul al-Fikih, terj. Saefullah Ma'shum, et al., cet. 9 (Jakarta: Pustaka Firdaus, 2005), 424.

58Amir Syarifuddin, Ushul Fikih ..., 334. 
b. Apa yang baik menurut akal itu, juga selaras dan sejalan dengan tujuan syara' dalam menetapkan hukum;

c. Apa yang baik menurut akal dan selaras pula dengan tujuan syara' tersebut tidak ada petunjuk syara' secara khusus yang menolaknya, juga tidak ada petunjuk syara' yang mengakuinya.

Sejalan dengan pengertian di atas, dapat ditarik sebuah keismpulan bahwa makna dari maslahah mursalab itu adalah menempatkan hukum dalam hal-hal yang tidak disebutkan pada Al-Qur'an, hadits maupun sunnah yang berguna bagi kehidupan manusia dengan menarik manfaat dan menghindari kerusakan.59

2. Syarat Maslabah Mursalab

Penerapan maslahah mursalah haruslah selaras dengan maqsid as syariah, yakni untuk mengasuh lima rukun kehidupan manusia diantaranya:60

a. Keselamatan keyakinana agama,

b. Keselamatan jiwa,

c. Keselamatan akal,

d. Keselamatan keluarga dan keturunan,

e. Keselamatan harta benda.

Lima rukun kehidupan di atasmenjadi patokan untuk mengatakan sesuatu itu maslahah atau tidak. Dengan ditetapkanya lima dasar kemaslahatan ini tidak semua yang di anggap maslabat oleh seorang itu menjadi ketentuan dalam menetapakan hukum. Adapun syarat-syarat yang harus dipenuhi untuk kemaslahatan yaitu:

a. Maslahah mursalah adalah maslahah yang hakiki, bukan bersifat umum, dalam artian bahwa maslahah mursalah dapat diterima oleh akal sehat dan benar-benar mendatangkan manfaat bagi manusia dan menghindarkan mudharat dari manusia secara utuh.61

59 Abdul Wahhab Khallaf, Imu Usbul Fikib (Semarang: Dina Utama, 1994), 116.

60 Rachmat Syafe'i, Ilmu Ushul Fikih (Bandung: Pustaka Setia, 1999), 61.

61 Saifuddin Zuhri, Ushul Fikih (Yogyakarta: Pustaka Pelajar, 2009), 84. 
b. Penetapan hukum untuk kemaslahatan ini tidak boleh bertentangan dengan hukum atau dasar yang ditetapkan dengan nash ataupun ijma'.62

c. Maslabah mursalah itu diamalkan dalam kondisi yang memerlukan, yang apabila masalahnya tidak diselesaikan dengan cara ini, maka maka umat akan berada dalam kesulitan hidup, dengan arti harus ditempuh untuk menghindarkan umat dari kesulitan.63

d. Maslahah mursalah harus sejalan dengan maksud-maksud syara' (Allah) dalam mensyari'atkan hukum, dan dapat diterima dan dicapai secara logis oleh akal sehat.64

3. Macam-Macam Maslahab Mursalab

Dalam rangka memperjelas pengertian maslabah mursalah, Abdul Karim Zaidab menjelaskan macam-macamnya:65

a. Maslabah mu'tabarah, yaitu maslahah yang secra tegas diakui syari'at dan telah ditetapkan suatu ketentuan-ketentuan hukum untuk merealisasikannya. Mislanya diperintahkan berjihad untuk menjaga agama dari rong-rongan musuhnya, ancaman hukuman zina untuk menjaga kehormatan dan keturunan, ancaman hukuman dari meminum khamr untuk merawat akal.

b. Maslahab mulgha, yaitu sesuatu yang dianggap maslahah oleh akal dan pikiran tetapi dianggap palsu karena kenyataan bertentangan dengan ketetntuan syari'at. Mislanya, ada anggapan bahwa menyamakan pembagian warisan anatara anak laki-laki dan perempuan adalah maslahah. Akan tetapi, kesimpulan seperti itu bertentangan dengan ketentuan syari'at yaitu ayat 11 surat an-Nisa' yang menegaskan bahwa pembagian anak laki-laki dua kali pembagian anak perempuan, adanya pertentangan itu menunjukkan bahwa apa yang dianggapa maslahat itu bukan maslahat di sisi Allah.

c. Maslahah mursalah, maslahat macam ini terdapat dalam masalah-masalah muamalah yang tidak ada ketegasan

62 Ibid.

63 Ibid.

64 Ibid.

65 Satria Effendi dan M Zein, Ushul Fiqh ..., 149-150. 
hukumnya dan tidak ada pula bandingannya dalam Al-Qur'an dan sunnah untuk dapat dilakukan analogi, contohnya peraturan lalu lintas dengan segala rambu-rambunya. Peraturan seperti ini tidak ada dalil khusus yang mengaturnya baik dalam Al-Qur'anmaupun dalam sunnah Rasulullah. Namun, peraturan seperti itu sejalna dengan tujuan syariat, yaitu dalam hal ini adalah menjaga jiwa dan harta.

Pertimbangan Hakim dalam Menetapkan Hak Hadanah Kepada Ibu Tri Pada Putusan Pengadilan Agama Sidoarjo Nomor: 0763/Pdt.G/2018/PA.Sda

Perkara ini pada awalnya merupakan permohonan cerai talak dan didalamnya terdapat perebutaan atas hak asuh anak atau hadanah, yang digugat oleh Penggugat Rekonvensi. Faktanya rumah tangga Penggugat Rekonvensi dan Tergugat Rekonvensi tidak dikaruniai anak namun sebelum menikah dengan Penggugat Rekonvensi, Tergugat Rekonvensi telah mempunyai seorang anak perempuan yang berumur 7 tahun dengan mantan isterinya terdahulu.

Majelis hakim memberi izin kepada Tergugat Rekonvensi untuk menjatuhkan talak satu raj'i terhadap Penggugat Rekonvensi dan memberikan hak asuh anak (badanah) kepada Penggugat Rekonvensi, sebagaimana diketahui Penggugat Rekonvensi merupakan ibu tiri dari anak tersebut. Oleh karena itu penulis bermaksud mengkaji dasar pertimbangan hakim dalam memutus perkara dalam putusan Pengadilan Agama Sidoarjo dengan nomor perkara 0763/Pdt.G/2018/PA.Sda yang dikeluarkan pada tahun 2018 tersebut.

Pertimbangan hakim yang memutuskan hak hadanab anak dilimpahkan kepada ibu tiri diberikan dengan alasan Tergugat Rekonvensi tidak keberatan hak asuh anak tersebut ditetapkan pada Penggugat Rekonvensi, dengan sayarat Tergugat Rekonvensi dan ibu kandungnya diberikan kebebasan untuk menjenguk dan memberikan kasih sayang kepada anak tersebut. Selain itu juga, majelis hakim mempertimbangkan untuk menjamin kemaslahatan hidup seorang anak yang pertimbangannya berdasarkan pada pasal 41 huruf (a) Undang-Undang Nomor 1 Tahun 1974 jo. pasal 156 
huruf (a) Kompilasi Hukum Islam, serta sesuai dengan dalil syar'i dalam Kitab Bajuri Juz II halaman 195:

"Apabila seorang laki-laki bercerai dengan isterinya, dan dia mempunyai anak dari perkawinannya dengan isterinya itu, isterinya lebih berhak untuk mengasuhnya".

Pertimbangan mengenai pihak yang berhak atas hadanah tidak dapat terlepas dari pasal 105 Kompilasi Hukum Islam yaitu, dalam hal terjadi perceraian maka pengasuhan anak yang belum mumayyiz. atau belum berumur 12 tahun adalah hak ibunya sedangkan pengasuhan anak yang sudah mumayyiz diserahkan kepada anak untuk memilih diantara ayah atau ibunya sebagai pemegang hak pengasuhannya dan mengenai biaya pengasuhan ditanggung oleh ayahnya.

Berdasarkan pasal 105 di atas dapat diketahui, bahwa orang yang berhak atas hak asuh anak atau hadanah adalah seorang ibu terlebih lagi apabila anak tersebut masih berusia dibawah 12 tahun dengan kata lain belum mumayyiz: Namun pada putusan Pengadilan Agama Sidoarjo Nomor: 0763/Pdt.G/2018/PA.Sda tersebut faktanya, Penggugat Rekonvensi bukan merupakan ibu kandung dari anak itu namun majelis hakim dalam hal ini menyimpulkan, berdasarkan dari keterangan Penggugat Rekonvensi serta saksi-saksi yang hadir saat persidangan maka pihak Penggugat Rekonvensi yang lebih berhak untuk mengasuh dan merawat, dikarenakan Penggugat Rekonvensi menyayangi dan mengasihi anak tersebut selayaknya anak kandung sedangkan ibu kandung anak tersebut tidak pernah memperdulikan anak tersebut, Tergugat Rekonvensi pun memberikan keterangan yang pada pokoknya tidak membantah adanya hal itu.

Tergugat Rekonvensi juga pernah menyatakan penolakan atas gugatan Penggugat Rekonvensi tersebut karena merasa Penggugat Rekonvensi tidak memiliki hak apapun atas anak yang merupakan anak kandung dari Tergugat Rekonvensi dengan mantan isteri terdahulunya, tetapi pada persidangan selanjutnya Tergugat Rekonvensi menyatakan bahwa tidak keberatan hadanah ditetapkan pada Penggugat Rekonvensi ditambah berdasarkan keteranagan saksi-saksi telah terbukti selama Penggugat Rekonvensi dan Tergugat Rekonvensi pisah ranjang sampai saat ini, anak tersebut 
diasuh baik oleh Penggugat Rekonvensi, maka gugatan Penggugat Rekonvensi tersebut patut dikabulkan.

Pemberian putusan terhadap hadanah bukanlah perkara yang mudah, hakim harus melihat fakta yang ada apakah Penggugat Rekonvensi telah memenuhi syarat-syarat sebagai pemegang hadanah, karena sesuai yang ada dalam kitab Kifayatul Akhyar Juz II, syarat untuk menjadi pemegang hadanah ada 7 yaitu:

"Syarat-syarat bagi orang yang akan melaksanakan tugas hadanah (pengasuhan) ada 7 (tujuh) macam: berakal sehat, merdeka, beragama Islam, iffah (sederhana), dapat dipercaya, bertempat tinggal tetap/satu tempat kediaman dengan anak yang diasuh, tidak bersuami/belum kawin lagi. Apabila salah satu syarat tidak terpenuhi, maka gugurlah hak hadhanah (pengasuhan) itu dari tangan ibu".

Sejalan dengan yang tercantum dalam kitab Kifayatu Akhyar di atas, Wahbah Az-Zuhaili dalam Fiqh Islam Wa Adrillatubu juga mengkategorikan syarat-syarat diantaranya: baligh, berakal, amanah, dapat mendidik dengan baik dan beragama Islam. Jika kita melihat redaksi kitab yang di atasmaka Tergugat Rekonvensi selaku ayah kandung tidak dapat memenuhi ke 7 syarat tersebut.

Dalam hal badanah yang terpenting adalah kehadiran sosok yang dapat menjadi pengawas, penjaga serta pendidik bagi anak. Namun nayatanya, kedua orangtua kandung anak tersebut tidak mampu memenuhi persyaratan yang ada seperti halnya ayah kandung atau Tergugat Rekonvensi tidak tinggal satu atap dengan anak, selain itu ayah kandung atau Tergugat Rekonvensi juga kedapatan berselingkuh dengan wanita lain sehingga Tergugat Rekonvensi tidak dapat dikategorikan orang yang amanah.

Ibu kandung dari anak tersebut sudah lama tidak pernah memperdulikan dan hilang tanpa kabar, tentu tidak akan dapat menjadi sosok penjaga dan pendidik seperti yang diharapkan, sementara telah jelas perintah dalam Alqur'an Q.S at-Tahrim ayat 6 yaitu:

"Hai orang-orang beriman, peliharalah dirimu dan keluargamu dari siksaan api neraka yang bahan bakarnya adalab manusia dan batubatu, sedang penjaganya malaikat-malaikat yang kasar lagi keras, 
mereka tiada mendurbakai Allab tentang apa-apa yang disurub-Nya dan mereka memperbuat apa-apa diperintabkan kepadanya".

Adapun hal-hal mengenai kewajiban orangtua untuk mengasuh anaknya telah tercantum dalam pasal 45 ayat (1) UndangUndang Nomor 1 Tahun 1974 tentang Perkawinan yang berbunyi "kedua orang tua wajib mengasuh dan mendidik anak-anak mereka sebaik-baiknya". Pasal tersebut memiliki relefansi dengan pasal 49 yang berisikan bahwa, salah seorang atau kedua orang tua dapat dicabut kekuasaannya terhadap seorang anak atau lebih untuk waktu tertentu atas permintaan orang tua yang lain, keluarga anak dalam garis lurus ke atas dan saudara kandung yang telah dewasa atau pejabat yang berwenang dengan keputusan pengadilan apabila ia sangat melalaikan kewajibannya terhadap anaknya atau ia berkelakuan buruk sekali. Meskipun orang tua dicabut kekuasaannya, mereka masih berkewajiban untuk memberi biaya pengasuhan kepada anak tersebut.

Berdasarkna uraian di atas, ditarik kesimpulan bahwa penetapan hak badanab untuk salah satu orang tuanya bukan merupakan penetapan yang permanen, karena hak pengasuhan anak sewaktu-waktu dapat dialihkan pada pihak lain. Hal ini bisa terjadi dengan mempertimbangkan perilaku dan sikap tanggung jawab dari orang tua, pengasuh atau pemegang hadanah.

\section{Analisis Maslahah Mursalah Terhadap Pertimbangan Hakim dalam Menetapkan Hak Hadanah Kepada Ibu Tiri Pada Putusan Pengadilan Agama Sidoarjo Nomor:
0763/Pdt.G/2018/PA.Sda.}

Putusan hakim Pengadilan Agama Sidoarjo menetapkan bahwa hak hadanah jatuh kepada Penggugat Rekonvensi yang merupakan ibu tiri dari anak tersebut, adapun majelis hakim menetapkan hal tersebut dengan pertimbangan-pertimbangan sebagai berikut:

Pertimbangan yang pertama, yaitu karena Tergugat Rekonvensi tidak keberatan hak hadanah ditetapkan kepada Penggugat Rekonvensi dengan catatan Tergugat Rekonvensi dan ibu kandungnya diberikan hak untuk menjenguk dan memberikan kasih sayang kepada anak tersebut. Ditambah oleh keterangan saksi-saksi yang menyatakan selama Tergugat Rekonvensi dan Penggugat 
Rekonvensi pisah ranjang, anak tersebut diasuh secara baik selayakanya anak kandung oleh Penggugat Rekonvensi.

Walaupun adanya persetujuan dari Tergugat Rekonvensi yang merupakan ayah kandung anak, mengenai hal hadanab tidak semua orang yang dikehendaki orangtua kandung berhak untuk mendapatkannya. Karena Islam juga telah mengatur urutan pemegang hadanah jika kedua orangtua kandung anak tidak berkompeten menjadi pengasuh, berikut adalah urutan bagi perempuan-perempuan yang dapat menjadi pemegang hadanah. Pertama adalah ibu anak tersebut, apabila ia tidak dapat memenuhi persyaratan yang diantaranya ialah baligh, berakal, memiliki kemampuan untuk mendidik, amanah, sederhana dan baelum menikah lagi maka hadanab diberikan kepada perempuanperempuan selainnya.

Perempuan-perempuan yang secara ijbari dapat menjadi pemegang hadanah ialah nenek dari ibu dan terus ke atas, nenek dari pihak ayah, saudara kandung anak, saudara perempuan seibu, saudara perempuan seayah, anak perempuan dari saudara perempuan sekandung, anak perempuan dari saudara perempuan seayah, saudara perempuan seibu dan sekandung dengannya, saudara perempuan ibu yang seibu dengannya (bibi), saudara perempuan ibu dan seayah dengannya (bibi), anak perempuan dari saudara perempuanseayah, anak perempuan dari saudara laki-laki kandung, anak perempuan dari saudara laki-laki seibu, anak perempuan dari saudara laki-laki seayah, bibi yang sekandung dengan ayah, bibi yang seibu dengan ayah, ibi yang seayah dengan ayah, bibi ibu dari pihak ibu, bibinya ayah dari pihak ibunya, bibi ibu dari pihak ayahnya, dan yang terahir bibi ayah dari pihak ayah,

Sesuai urutan yang telah disebutkan sebelumnya, maka Penggugat Rekonvensi tidak memiliki kedudukan kuat untuk menggugat hak dalam hal hadanah karena Penggugat Rekonvensi tidak memiliki hubungan mabram bahkan bukan kerabat dari anak tersebut. Adanya fakta bahwa ibu kandung tidak diketahui keberadaannya ditambah lagi Tergugat Rekonvensi menyetujui anak diasuh oleh Penggugat Rekonvensi, dalam hal ini majelis hakim mempertimbangkan faktor persetujuan dari Tergugat Rekonvensi. 
Faktor penguat lainnya adalah merujuk pada keterangan saksisaksi yang menyatakan jika anak tersebut dirawat dengan penuh kasih sayang layaknya anak kandung. Selain itu, sikap dan sifat Penggugat Rekonvensi juga sejalan dengan syarat-syarat orang yang dapat menjadi pemegang hadhanah yang tercantum dalam kitab Kifayatul Akbyar juz II, yaitu:

"Syarat-syarat bagi orang yang akan melaksanakan tugas badanah (pengasuhan) ada 7 (tujuh) macam: berakal sehat, merdeka, beragama Islam, iffah (sederhana), dapat dipercaya, bertempat tinggal tetap/satu tempat kediaman dengan anak yang diasuh, tidak bersuami/belum kawin lagi. Apabila salah satu syarat tidak terpenuhi, maka gugurlah hak hadhanah (pengasuhan) itu dari tangan ibu".

Keputusan majelis hakim untuk memberikan hak hadanah kepada Penggugat Rekonvensi berdasarkan hal yang telah disebutkan di atassudah tepat, karena memiliki relevansi dengan hakikat dari hadanah itu sendiri yang mana diperuntukkan bagi kemaslahatan dan kelangsungan hidup anak agar nantinya dapat tumbuh berkembang menjadi pribadi yang baik dibawah pengasuhan orang yang tepat. Melalui hal-hal yang telah disebutkan sebelumnya, dapat diketahui jika hak hadanah tidak selamanya diperuntukkan bagi orangtua kandung melainkan juga melihat sisi kemampuan seseorang selaku pengasuh anak yang sekiranya tidak akan mendatangkan kerusakan bagi anak dimasa tumbuh kembangnya. Hal ini sejalan dengan kaidah fikih yang berbunyi:

"Jika terjadi pertentangan antara dua macam mufsadat, maka harus diperhatikan mana yang lebih besar bahayanya dengna melakukan yang lebih ringan".

Pertimbangan kedua, berdasarkan pasal 41 huuruf (a) Undang-Undang Nomor 1 Tahun 1974 jo. pasal 105 dan pasal 156 huruf (a) Kompilasi Hukum Islam, sesuai dengan dalil syar'i dalam Kitab Bajuri juz II halaman 195:

"Apabila seorang laki-laki bercerai dengan isterinya, dan dia mempunyai anak dari perkawinannya dengan isterinya itu, isterinya lebih berhak untuk mengasuhnya".

Berdasarkan penggalan dalil kitab di atas, bahwa ibu lah orang yang paling berhak atas hadanah, namun diketahui ibu kandung anak 
tersebut tidak pernah memperdulikan anak. Maka, akan berbahaya jika anak berada dibawah asuhan ibu kandung dan hal tersebut akan lebih banyak mafsadat ketimbang maslahahnya sementara yang kita ketahui bahwa mafsadat sebaiknya dihindari. Hal ini sesuai dengan teori maslahah mursalah, menggunakan kaidah fikih:"Segala mudharat (bahaya, kerugian) harus dihilangkan"

Alasan penyelesain perkara hadanah yang dilimpahkan kepada ibu tiri di Pengadilan Agama Sidoarjo ini sejalan dengan teori maslabah mursalab adalah:

1. Apabila hak hadanah anak dilimpahkan kepada ibu kandung maka kemungkinan anak tersebut tidak akan mendapatkan sebuah perlindungan maupun pendidikan yang baik. Walaupun ini hanya sekedar dugaan akan tetapi melalui fakta yang ada jika selama bertahun-tahun ibu kandung hilang kabar dan tidak memperdulikan anak tersebut maka demi menghindari mafsadat, keputusan hakim untuk memberikan hak hadanah kepada ibu tiri merupakan hal yang benar dan sesuai dengan tujuan dari maslabah mursalah.

2. Apabila hak hadanah dilimpahkan kepada ayah kandung atau Tergugat Rekonvensi, untuk kedepannya dan dalam masa pertumbuhan si anak akan kekurangan kasih sayang begitu pula dalam hal pendidikan dan perlindungan sebagaimana yang diharapkan. Itu semua dikarenakan ayah kandung atau tegugat rekonvensi tidak dapat menjadi figur yang baik untuk anak, Penggugat Rekonvensi kedapatan berselingkuh atau memiliki wanita idaman lain, bahkan selama pisah ranjang anak tersebut diasuh oleh Tergugat Rekonvensi atau ibu tirinya. Sifat dari ayah kandung atau Tergugat Rekonvensi tersebut merupakan contoh yang tidak baik dan kedepannya dapat membahayakan tumbuh kembang anak.

3. Apabila hak hadanah dilimpahkan kepada ibu tiri atau Tergugat Rekonvensi yang dalam hal ini tidak memiliki hubungan nasab maupun kekerabatan dengan anak tersebut, maka itu akan menjadi lebih baik karena bagaimanapun Penggugat Rekonvensi walaupun sebagai ibu tiri telah menganggap anak Tergugat Rekonvensi bersama mantan isteri terdahulunya seperti anak kandung. Maka besar kemungkinan untuk kedepannya dari segi 
pengasuhan, pendidikan, bahkan perlindungan akan lebih terjamin dibandingkan orangtua kandung. Selain itu juga ibu tiri atau Penggugat Rekonvensi merupakan figur teladan yang baik dibandingkan ayah kandung maupun ibu kandung anak tersebut.

Berdasarkan uraian di atas, keputusan majelis hakim mengenai hak hadanah yang diberikan kepada ibu tiri telah sesuai dengan teori yang ada dalam hukum Islam yaitu maslabah mursalah yakni mengambil manfaat dan menolak mudharat, karena putusan tersebut merupakan keputusan yang terbaik untuk kepentingan anak. Walaupun jika dilihat pada dalil-dalil yang ada di Al-Qur'an, Sunnah maupun Kompilasi Hukum Islam, status Penggugat Rekonvensi yaitu seorang ibu tiri tidak termasuk dalam golongan orang yang berhak atas hadanah.

Pada ahirnya dapat disimpulkan bahwa pelimpahan hak asuh anak atau hadanah tidak serta merta mempertimbangkan terhadap adanya hubungan darah ataupun kekerabatan saja, melainkan dilihat dari segi kesiapan orang yang akan menjadi pemegang hadanah. Hadanah, tidak selamanya diperuntukkan bagi orangtua kandung melainkan dilihat segi kemampuan orang selaku pengasuh anak tersebut yang sekiranya tidak mendatangkan kerusakan bagi diri anak, dalam hal ini hakim mengukur dari segi kelayakan dan kemampuan Penggugat Rekonvensi dan Tergugat Rekonvensi yang bertujuan supaya kelak anak tersebut dapat menerima kasih sayang, perlindungan serta pendidikan yang baik.

Hal terbaik ialah dengan menempatkan anak tersebut tinggal bersama ibu tiri atau Penggugat Rekonvensi, dalam hal ini ibu tiri atau Penggugat Rekonvensi nyatanya lebih layak dan berkompeten untuk mendapatkan hak hadanah tersebut dan gugatannya patut dikabulkan oleh majelis hakim Pengadilan Agama Sidoarjo.

\section{Penutup}

Pertimbangan hakim dalam menetapkan hak hadanah kepada ibu tiri pada putusan Pengadilan Agama Sidoarjo Nomor: 0763/Pdt.G/2018/PA.Sda didasarkan pada pasal 41 huruf (a) Undang-Undang Nomor 1 Tahun 1974 jo. pasal 105 dan pasal 156 huruf (a) Kompilasi Hukum Islam serta dalil dalam kitab Bajuri juz II. Selain itu, adanya kerelaan dari Tergugat Rekonvensi yang merupakan ayah kandung dari anak tersebut untuk memberikan hak 
hadanah kepada Penggugat Rekonvensi merupakan point yang dimasukkan sebagai pertimbangan oleh majelis hakim.

Dalam hukum Islam yang dikaji dari teori maslabah mursalah, pertimbangan hakim untuk menetapkan hak hadanab kepada ibu tiri pada putusan pengadilan Agama Sidoarjo Nomor: 0763/Pdt.G/2018/PA.Sda telah sesuai dengan tujuan dari hadanah yaitu mengutamakan kepentingan dan kemaslahatan anak agar nantinya dapat tumbuh berkembang menjadi pribadi yang baik dibawah pengasuhan orang yang tepat, walaupun anak tersebut bukan merupakan anak kandung dari Penggugat Rekonvensi namun Penggugat Rekonvensi nyatanya lebih layak dan berkompeten untuk memiliki hak badanah.

\section{Daftar Pustaka}

A Rasydi Roihan. Hukum Acara Peradilan Agama. Jakarta: PT Raja Grafindo Persada, 2007.

Abdul Azis Dahlan. Ensiklopedi Hukum Islam. Jakarta: Ichtiar Baru Van Heove,1999.

Abdul Manan. Etika Hakim Dalam Penyelenggaraan Peradilan. Jakarta: Kencana, 2007.

Abdul Rahman Ghazaly. Fiqh Munakahat. Jakarta: Pranada Media Grup, 2003.

Abdul Wahhab Khallaf. Ilmu Ushul Figh. Semarang: Dina Utama, 1994.

Ahmad Kuzari. Nikah Sebagai Perikatan. Jakarta: Raja Grafindo, 1995.

Ahmad Rofiq. Hukum Islam di Indonesia. Jakarta: PT Raja Grafindo Persada, 1998.

Amir Syarifuddin. Hukum Perkawinan Islam di Indonesia: Antara Fiqh

Munakahat dan Undang-Undang Perkawinan. Kencana: Prenada Media, 2006.

Amir Syarifuddin. Ushul Fiqih. Jakarta: Logos Wacana Ilmu, 1999.

Amiur Nuruddin Taringan dan Azhari Akmal. Hukum Perdata Islam

Di Indonesia, Studi Kritis Pekembangan Hukum Islam dan Fikih, UU No. 1/1974 Sampai KHI. Jakarta: Kencana Prenada Media Group, 2006. 
Andi Syamsu Alam Fauzan dan M. Hukum Pengangkatan Anak Perspektif Islam. Jakarta: Kencana Prenada Media Group, 2008.

Departemen Agama RI. Al-Quran dan Terjemabnya, Diponegoro: AlHikmah, 2007.

Diibulbigha, Mustofa. Fiqih Syafi i. Bandung: CV Bintang Pelajar, 1998.

Djamaan Nur. Fiqib Munakahat. Semarang: Dina Utama, 1993.

Fahrur Rozi. "Tinjauan Hukum Islam Terhadap Penolakan Majelis Hakim Atas Hak Asuh Anak Oleh Suami (Studi Putusan Nomor: 0138/Pdt.G/2013/PA.Mlg)”. Penelitian--UIN Sunan Ampel, Surabaya, 2015.

Joko Subagyo. Metode Penelitian Dalam Teori dan Praktek. Jakarta: PT. Rineka Cipta, 2004.

M. Abdul Ghofar. Fiqh Wanita. Jakarta: Pustaka Al-Kautsar, 2006. Mahkamah Agung RI Direktorat Jendral Badan Peradilan Agama, Pedoman Pelaksanaan Tugas dan Administrasi Peradilan Agama Buku II Tahun 2013.

Mestika Zed. Metodologi Penelitian Kepustakaan. Jakarta: Yayasan Obor Indonesia, 2004.

Muhammad Abu Zahrah. Ushul Al-Fiqh. Ushul Fiqih. Jakarta: Pustaka Firdaus, 2005.

Muhammad Rawwas Qal'ahji. Ensiklopedi Fiqh Umar Bin Khathab. Jakarta: Raja Grafindo Persada, 1999.

Muhdlar, Atabiq Ali dan Ahmad Zuhdi Muhdlar. Kamus Kontemporer Arab-Indonesia. Yogyakarta: Yayasan Ali Maksum Pondok Pesantren Krapyak, 1996.

Mukti Arto. Praktek Perkara Perdata Pada Pengadilan Agama. Yogyakarta: Pustaka Pelajar, 2014.

Munawar Kholil. Kembali Kepada Al-Quran dan As-Sunnah. Jakarta: Bulan Bintang, 1965.

Rachmat Syafe'i. Ilmu Ushul Fiqh. Jakarta: Prenada Media Group, 2010.

Romli, Muqaranah Mazahib Fil Ushul. Jakarta: Gaya Media Pratama, 1999.

Sahrani, Tihami dan Sahari. Fiqh Munakahat: Kajian Fiqh Nikah Lengkap. Jakarta: Rajawali Pers, 2010. 
Saifuddin Zuhri. Ushul Fiqih. Yogyakarta: Pustaka Pelajar, 2009. San'ani, (ash). Subulus Salam, cet. 3. Surabaya: Al-Ikhlas, 1995.

Satria Effendy Zein dan M. Problematika Hukum Keluarga Islam Kontemporer Analisis Yurisprudensi Dengan Pendekatan Ushuliyah. Jakarta: Kencana, 2010.

Sayyid Sabiq. Fiqih Al-Sunnah III. Jakarta: Pena Pundi Aksara, 2006.

Seomiyati, Hukum Perkawinan Islam dan Undang-Undang Perkawinan. Yogyakarta: Liberty, 2007.

Slamet Abidin dan H. Aminuddin. Fikih Munakahatii. Bandung: CV Pustaka Setia, 1999.

Suharsimi Arikunto. Prosedur Penelitian Suatu Pendekatan Praktek. Jakarta: Rineka Cipta, 1997.

Suprapto. "Study Kasus Terhadap Putusan

No.1361/Pdt.G/2006/PA.Sby Tentang Sengketa Hak Asuh Anak Sebelum Mumayyiz. Akibat Perceraian". Penelitian--IAIN Sunan Ampel, Surabaya, 2007.

Suwarjin. Ushul Fiqh. Yogyakarta: Teras, 2012.

Syahrani, Riduan. Buku Materi Dasar Hukum Acara Perdata. Bandung: PT Citra Aditya Bakti, 2009.

Syaikh Hasan Ayyub. Fikih Keluarga Panduan Membangun Keluarga Sakinah Sesuai Syariat. Jakarta: Pustaka Al-Kautsar, 2008.

Ahmad Tantowi. "Argumentasi PA Surabaya Menolak Hak Pengasuhan Ibu Pada Anak yang Belum Mumayyiz". Penelitian--IAIN Sunan Ampel, Surabaya, 2003.

Undang-Undang Republik Indonesia Nomor 1 Tahun 1974 Tentang Perkawinan dan Kompilasi Hukum Islam.

Wahyu Ernaningsih Samawati dan Putu. Hukum Perkawinan Indonesia. Palembang: PT. Rambang Palembang, 2008.

Zakiyah Daradjat. Ilmu Fiqih Jilid 2. Yogyakarta: Dana Bhakti Wakaf, 1995.

Putusan Pengadilan Agama Sidoarjo Nomor: 0763/Pdt.G/2018/PA.Sda. 